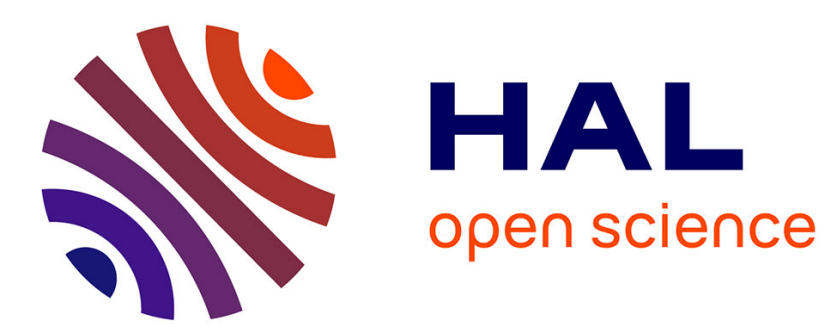

\title{
Science at the policy interface: volcano-monitoring technologies and volcanic hazard management
}

Amy Donovan, Clive Oppenheimer, Michael Bravo

\section{To cite this version:}

Amy Donovan, Clive Oppenheimer, Michael Bravo. Science at the policy interface: volcano-monitoring technologies and volcanic hazard management. Bulletin of Volcanology, 2012, 74 (5), pp.1005-1022. 10.1007/s00445-012-0581-5 . insu-00723551

\section{HAL Id: insu-00723551 https://hal-insu.archives-ouvertes.fr/insu-00723551}

Submitted on 28 Aug 2012

HAL is a multi-disciplinary open access archive for the deposit and dissemination of scientific research documents, whether they are published or not. The documents may come from teaching and research institutions in France or abroad, or from public or private research centers.
L'archive ouverte pluridisciplinaire HAL, est destinée au dépôt et à la diffusion de documents scientifiques de niveau recherche, publiés ou non, émanant des établissements d'enseignement et de recherche français ou étrangers, des laboratoires publics ou privés. 


\title{
Science at the policy interface: volcano-monitoring technologies and volcanic hazard management
}

Amy Donovan ${ }^{1,2}$, Clive Oppenheimer ${ }^{3,4,1}$ and Michael Bravo ${ }^{2}$

(1) Department of Geography, University of Cambridge, Downing Place, Cambridge, CB2 3EN, UK

(2) Scott Polar Research Institute, University of Cambridge, Lensfield Road, Cambridge, CB2 1ER, UK

(3) Le Studium, Institute for Advanced Studies, Orléans and Tours, France

(4) Institut des Sciences de la Terre d'Orléans, University of Orléans, 1a rue de la Férollerie, 45071 Orléans, Cedex 2, France

\begin{abstract}
This paper discusses results from a survey of volcanologists carried out on the Volcano Listserv during late 2008 and early 2009. In particular, it examines the status of volcano monitoring technologies and their relative perceived value at persistently and potentially active volcanoes. It also examines the role of different types of knowledge in hazard assessment on active volcanoes, as reported by scientists engaged in this area, and interviewees with experience from the current eruption on Montserrat. Conclusions are drawn about the current state of monitoring and the likely future research directions, and also about the roles of expertise and experience in risk assessment on active volcanoes; while local knowledge is important, it must be balanced with fresh ideas and expertise in a combination of disciplines to produce an advisory context that is conducive to high-level scientific discussion.
\end{abstract}

Keywords Science and policy - Risk - Uncertainty - Volcano monitoring - Volcanic hazards

\section{Introduction: monitoring volcanoes and scientific progression in volcanology}

The last decade has witnessed extensive growth in the availability of technologies for monitoring volcanoes. Much of this development has involved collaborations between volcano observatories and researchers around the world. At the same time, however, resources at observatories may be stretched and there can a great deal of pressure on scientists to justify their purchase of new equipment. The use of different monitoring technologies in integrated monitoring systems on active volcanoes has also increased significantly in the last decade, with wider funding of multidisciplinary international projects (e.g. Galle et al. 2010). New technologies have been developed to monitor long-recognised valuable signals of volcanic activity including seismicity, gas geochemistry and ground deformation, and to develop the application of other areas such as electromagnetic field surveillance (e.g. Zlotnicki et al. 2006). With new observatories being set up to monitor volcanoes, a key question for scientists concerns budgeting: governments and relevant authorities can be reluctant to fund multiple monitoring techniques if they are unconvinced of their worth. For example, the UK Department for International Development was criticised in 2004 for failing to fund research as well as baseline monitoring on Montserrat (House of Commons Science and Technology Committee 2004). 
The role of scientists as policy advisors has been much discussed in the social scientific literature, particularly in the fields of climate change, biotechnology and medicine (e.g. Shackley and Wynne 1995, 1996; Jasanoff 1990, 2004, 2005; Rayner 2003; Wynne et al. 2007; Brown 2009; Fischer 2010; Hulme and Mahony 2010). Expertise in the political context can be questioned for political and social reasons, as well as specialist ones, placing scientists under pressure to justify results and recommendations to laypeople. The democratising of expertise (Fischer 2010; Brown 2009) has implications for volcanologists, particularly given that volcanological advice may be required under crisis conditions, and may feed into policy decisions about costly evacuations (e.g. Marzocchi and Woo 2009). While many volcanoes are not adequately monitored (Ewert and Newhall 2004; Ewert et al. 2005), monitoring networks have frequently provided the main source of information about volcanic unrest (e.g. Sigmundsson et al 2010; Voight et al. 1999; Newhall and Punongbayan 1996), and the importance of monitoring active volcanoes is widely asserted in the literature (e.g. Tilling 2008). However, the relative infrequency of volcanic eruptions has also provoked political criticism of budgeting for volcano monitoring. Where resources for monitoring are limited, scientists have to justify their choice of technologies and techniques.

\section{Volcano monitoring and the convergence of disciplines}

Monitoring volcanoes typically involves the integration of a number of disciplines, the most common being seismology, ground deformation and gas geochemistry (based on a survey of observatory websites). Seismology is generally regarded as the most reliable of these. However, the practice of volcano seismology varies widely between locations. The monitoring of a particular volcano typically involves a network of seismic stations, preferably more than four to allow location of hypocentres. There are several different typologies of seismic signal, and there is some variation between volcanoes (McNutt 1996). Types include volcano-tectonic (high frequency) earthquakes, attributed to brittle fracture of rock at depth, long-period (low frequency) earthquakes, which may relate to fluid transport and deformation (e.g. Kumagai and Chouet 1999); and volcanic tremor (e.g. Benoit and McNutt 1997). In addition, some volcanoes generate hybrid earthquakes, which have both high- and lowfrequency components (e.g. Lahr et al. 1994; De Angelis et al., 2007), very long period earthquakes (e.g. Rowe et al. 1998), and/or deep high-frequency earthquakes (McNutt 1996). The use of broadband seismometers has significantly improved the resolution and range of signals detectable from volcanoes, and this has generated new methods for the interpretation and analysis of signals (e.g. Roman et al. 2006; Sandri et al. 2004; Neuberg et al. 1998, 2006; Chouet 1996; Chouet et al. 2003; McNutt 1996).

Ground deformation monitoring involves the use of tiltmeters, electronic distance measurements and Global Positioning System (GPS) receivers to monitor surface movements at volcanoes: inflation may be caused, for example, by rising and/or vesiculating magma. Similarly, during an eruption, the ground may deflate as magma is discharged. Ground deformation model typically posit a source with simple geometry and try to fit it to the observed deformation (Mogi 1958; Jousset et al. 2003; Fialko et al. 2003), and finite element modelling methods have enabled increasingly detailed modelling of crustal dynamics (e.g. Foroozan et al. 2010; Fialko et al. 2003). However, ground deformation can also be caused by hydrothermal activity, and this has been the source of divided opinion on interpretation of data, a key example being Campi Flegrei in Italy (Bellucci et al. 2005; Bonafede 1991). The eruption of Soufriere Hills Volcano, Montserrat, has produced a well-studied deformation pattern of inflation during phases of quiescence, and deflation during extrusive episodes (Voight et al. 1998, 1999, 2010; Wadge et al. 2006, 2010; Foroozan et al. 2010). 
Gas geochemical monitoring can provide information about the depth and amount of magma in the crust. Currently, some observatories still carry out in situ sampling with Giggenbach bottles, while some have spectrometers (Galle et al. 2010; Oppenheimer et al. 2003). In recent years, ultraviolet spectroscopy for SO2 measurement has become widespread, using the differential optical absorption spectroscopy (DOAS) technique, which is more practical and affordable than correlation spectroscopy (e.g. McGonigle and Oppenheimer 2003). The use of spectroscopy is growing, but the instruments are vulnerable and several are needed to provide good coverage of the drifting plume (Edmonds et al. 2003; Salerno et al. 2009a, $b$; Burton et al. 2009; Galle et al. 2010). Data processing is time-consuming and labour-intensive (e.g. Kern et al. 2010), and spectroscopic flux measurements may be subject to high errors. A further development is the SO2 camera (e.g. Mori and Burton 2006). While SO2 is perhaps the most commonly monitored volcanic gas because it is abundant at active volcanoes but not otherwise present in large quantities in the atmosphere, recent results using Fourier-Transform infrared spectroscopy (FTIR) to monitor $\mathrm{HCl}, \mathrm{HF}$ and $\mathrm{H} 2 \mathrm{~S}$ have been shown to be promising (e.g. Edmonds et al. 2001; Burton et al. 2003). Multigas sensors have also been deployed to analyse $\mathrm{H} 2 \mathrm{O}, \mathrm{CO} 2$ and SO2 together (Aiuppa et al. 2010; Edmonds et al. 2010).

There are a variety of other monitoring methods, including infrasound (e.g. Ripepe et al. 2010), resistivity (e.g. Jackson et al. 1985), microgravity (e.g. Rymer 1994) and petrological laboratory tools (e.g. Corsaro and Miraglia 2005; Cashman and Taggart 1983). These are currently in various stages of development, and are mostly employed at observatories with healthier funding, or by university scientists in collaboration with observatories. There is therefore a very wide breadth of expertises required for volcano monitoring, and therefore a complex communicative process across disciplines. At some observatories, this also involves communication with social scientists, whose role includes risk perception surveys and outreach. There have recently been a number of attempts to use public participation in workshops as a means of developing risk management plans and maps (e.g. Cronin et al. 2004).

\section{Uncertainty and expertise: applying volcano monitoring and other types of knowledge in advisory contexts}

There are many sources of uncertainty during a volcanic eruption, including instrument error, model error, choice of models, processing error, interpretative error, population behaviour, 'unknown unknowns' and language issues. In the provision of scientific advice, monitoring data and its analysis may be combined with modelling results, geological data, local knowledge about the physical and social characteristics of the area, and social scientific data, requiring interdisciplinary communication between scientists, as well as communication with policymakers. Interdisciplinary communication for the purpose of providing expert advice has been discussed in other fields. Collins (2004) and Collins and Evans (2007) discuss the concept of 'interactional expertise': the ability to engage with academic disciplines at a level that allows one to understand and draw on multiple disciplines, but not necessarily contribute to cutting-edge research ('contributory expertise'). Interactional expertise would ideally include a working knowledge of the uncertainties inherent in particular types of data, for example.

Recent studies in the science and policy field have discussed the relationship between risk and uncertainty (Wynne 1992; Stirling 2007; Spiegelhalter and Riesch 2011). The climate change discourse in particular has yielded some important results in this area (Giddens 2010; Hulme 2009; Morgan et al. 2009), since political decisions about climate change have to be based on 
uncertain science - and this has on occasion been extremely controversial, not least in the socalled 'climategate' episode. Fundamentally, these discourses relate to the public perception of science; in the UK, the public generally view science as a source of certainty, whereas in practice it is characterised by uncertainty not only in the form of error, but also in subjective judgements, model parameterization, data collection and representation of results. A schema drawn up by Stirling (2007), which in turn draws on the work of Wynne (1992) shows risk, uncertainty, ambiguity and ignorance as definitions of incomplete knowledge of likelihood and/or outcome. It has been suggested that there is a 'closing down' towards risk in the case of technological governance (Stirling 2008), where risk involves knowledge of both the outcome and its probability. The danger of this is that non-technical types of knowledge are omitted. Figure 2 shows a schema based on Wynne (1992) and Stirling (2007), adapted for volcanic risk. This diagram demonstrates the ways in which some of the different types of knowledge mentioned in this paper seek to reduce uncertainty to something that can be represented quantitatively.

The extent of the dependence on science in volcanic crises may be much greater than for other areas of scientific governance. There is nothing that can be done reliably to reduce the volcanic activity itself - the requirement is therefore to decide on the necessity of costly evacuations, and long-term land-use planning. While this should be a decision for policymakers, the absolute dependence on scientific advice often means that in practice scientists are asked to make decisions, perhaps in the form of alert levels, which may be directly linked to particular civil protection actions. However, many scientists feel very strongly that this is extremely dangerous and far exceeds their role as scientists. Difficulties arise when the boundaries become unclear, or people are put under pressure. This is perhaps particularly likely in a crisis situation at a volcano where scientists, officials and the public are poorly prepared and decisions have to be made quickly under high levels of uncertainty. Bayesian Event Trees (Marzocchi et al. 2004, 2008) and volcanic risk metrics (Marzocchi and Woo 2007, 2009) provide innovative quantitative approaches to decision making, exemplified for the Auckland Volcanic Field by Lindsay et al. (2010). This does however involve preexisting collaborative relationships between local officials and scientists, and a supply of scientific data about the volcanic conditions.

Marzocchi and Zechar (2011) discuss the different types of uncertainty involved in seismic hazard assessment - a field that has arguably encountered some similar challenges to volcanology. Seismic hazard assessments vary in the degree to which subjective probabilistic methods are used, with some being heavily dependent on expert judgement (e.g. Hanks et al. 2009). As Marzocchi and Zechar (2011) note, probabilities are frequently subjective and cannot be verified or falsified (unless $P=0$ or 1), and all Bayesian methods involve a degree of subjectivity. However, these methods are more effective at representing uncertainty not simply from the variability of the natural system (aleatory) but also from lack of knowledge (epistemic). An important summary of recent relevant developments in earthquake hazard assessment is provided by Jordan et al. (2011), who note the importance of probabilistic forecasts for risk managers. It should also be noted that the use of probabilistic methods does not take into account the broader social context both of science and its application (Fig. 1). These are uncertainties that are not easily quantified. 


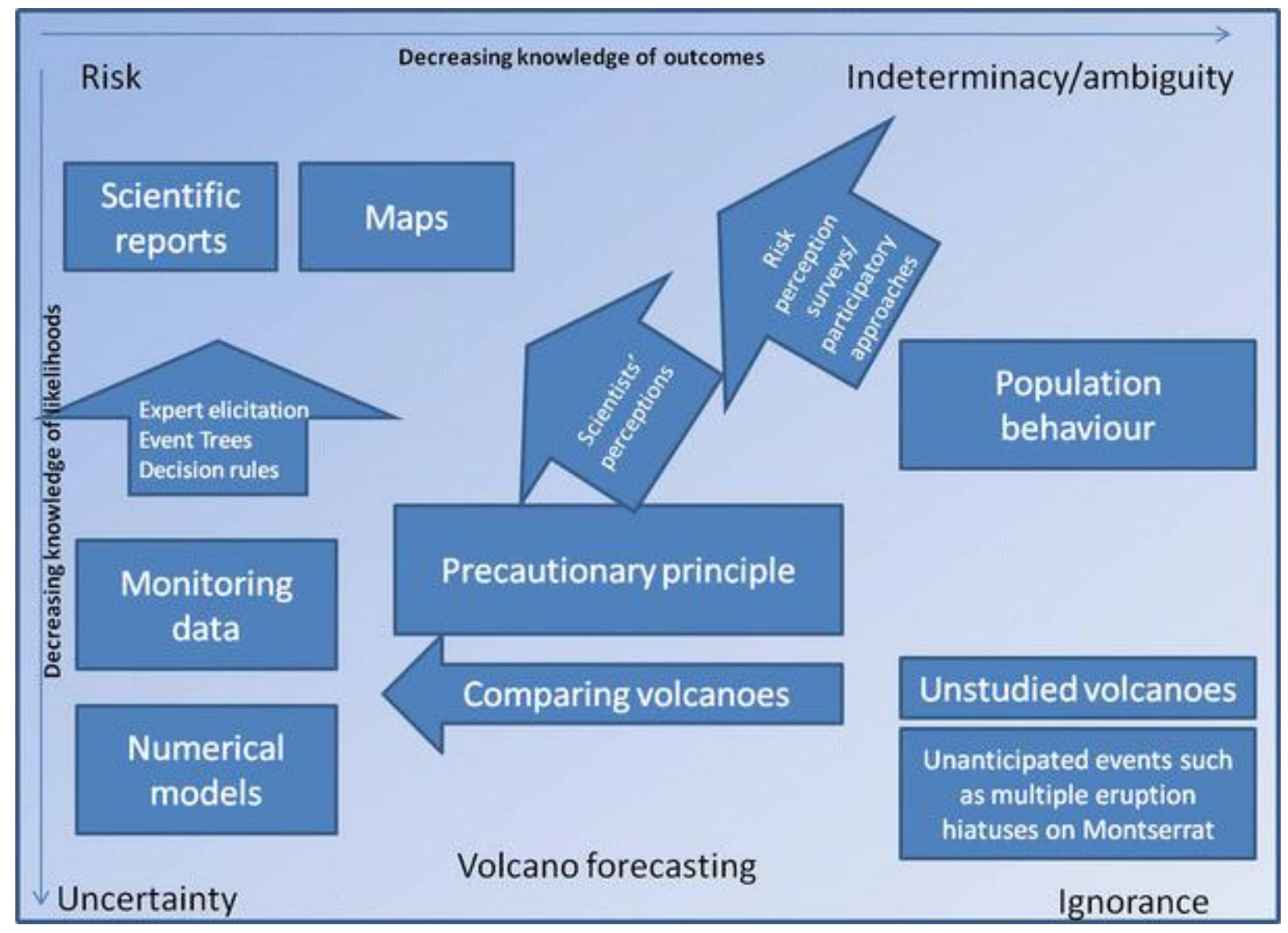

Fig. 1 Summary of types of information, knowledge and uncertainty that may be employed in the management of an active volcano. Arrows indicate methods that seek to move from one condition to another-for example, using subjective probabilistic methods to quantify risk based on monitoring data and numerical models

The separation of risk assessment and risk management is rarely straightforward (Stirling 2007), and also relates to public understanding of scientific uncertainty: specifically in this case, the reliability of forecasting of volcanic activity. In addition, the relative infrequency of volcanic disasters means that there is a danger that the expertise of those experienced in crisis assessment will be lost. This paper presents data from a survey carried out in 2008-2009 concerning volcano monitoring and communication within and beyond the scientific community. In particular, the usefulness of different monitoring technologies, anticipated directions in monitoring, and aspects of hazard management were assessed. The eruption on Montserrat is used as a case study to discuss the role of scientists in providing policy advice on active volcanoes under conditions of uncertainty. The paper therefore combines information about scientific monitoring with reflections on the process by which monitoring is discussed and applied in the policy context. This relates both to decisions about the use of public funding for particular monitoring technologies and to the application of scientific results to policy decisions about land use on active volcanoes.

\section{Methods}


This article discusses results from a multidisciplinary project examining volcanology in its social context, combining quantitative and qualitative methods. These were a survey of volcanologists, interviews with scientists and local officials, and participant observation. The survey data covers volcanologists from a range of countries and backgrounds. The survey was used to identify trends and ideas, which were then examined in more detail using qualitative methods. Much of this was done on Montserrat, and is therefore narrower in scope than the survey.

\section{Survey}

A survey was carried out on 'Volcano Listserv' in 2008-2009 with 186 respondents. Many of those who responded had worked at or had affiliation with volcano observatories. The data reported below relate to monitoring technologies and to the types of interaction involved in communicating scientific advice. The data were assessed using a range of statistical tests (Field 2000), which are described in detail in the 'Appendix' section, and more briefly in Table 1. Initial exploration of the dataset using a range of normality tests was used to identify those questions that required non-parametric testing.

Table 1 Summary of statistical tests

\begin{tabular}{|c|c|c|}
\hline Test & Sym & Significance \\
\hline Kruskal-Wallis & $H$ & Compares the medians of several groups (non-parametric test) \\
\hline Mann-Whitney & $U$ & $\begin{array}{l}\text { Compares the medians of two groups (can be used as a test for } \\
\text { the results of the Kruskal-Wallis test, and is also non- } \\
\text { parametric) }\end{array}$ \\
\hline Spearman's Rho & $\rho$ & Non-parametric correlation coefficient \\
\hline Factor analysis & $N / A$ & $\begin{array}{l}\text { Uses the data correlation matrix and its eigenvalues to identify } \\
\text { latent factors in the data }\end{array}$ \\
\hline $\begin{array}{l}\text { Reliability analysis } \\
\text { (Cronbach) }\end{array}$ & $\alpha$ & Assesses the reliability of a scale \\
\hline$z$-Score & $z$ & Normalises deviations from the mean \\
\hline Effect size & $r$ & Measures the magnitude of a statistical effect \\
\hline $\begin{array}{l}\text { Jonckeheere- } \\
\text { Terpstra }\end{array}$ & $J$ & Looks for trends within ranked medians \\
\hline$T$ test & $t$ & Compares two means \\
\hline
\end{tabular}

\section{Fieldwork}


Participant observation and interviews were carried out during two 10-week field seasons at the Montserrat Volcano Observatory in 2008 and 2009. Further interviews were carried out in a 5-week period in Iceland, and 5 weeks were spent carrying out interviews and participant observation in Sicily. Interviews were semi-structured (Somekh and Lewin 2005) and ranged between 30 and $120 \mathrm{~min}$ in duration. Interviewees included observatory scientists, technicians, academic scientists with advisory roles, policymakers and local government officials.

Participant observation is an anthropological research method that is used in the study of cultures (Geertz 1973). It is a highly subjective method, relying on the observations and responses of the researcher to provide insights into the culture in question - in this case, observatory volcanology. Its use in understanding scientific cultures in particular is well documented (Latour 1987; Traweek 1988; Collins 1985). In this paper, the case study of Montserrat is used to provide some qualitative insights into the quantitative results. The eruption of the Soufriere Hills Volcano on Montserrat began in 1995 (Druitt and Kokelaar 2002) following 3 years of elevated seismicity (Young et al. 1998). It is an andesitic domebuilding eruption (e.g. Sparks and Young 2002; Watts et al. 2002), and has resulted in the evacuation and subsequent destruction of the capital city, Plymouth. The Montserrat Volcano Observatory was set up in 1995 to monitor the volcano and advise the government on the activity (Aspinall et al. 2002). It has been assisted in this role by external scientists, and an official Scientific Advisory Committee was set up in 2003. During the period covered by this study, the Scientific Advisory Committee (SAC) was meeting every 6 months to carry out a risk assessment. Risk assessments on Montserrat involve a range of probabilistic methods, including expert elicitation (Aspinall 2006, 2010), Bayesian event trees (e.g. Newhall and Hoblitt 2002), Bayesian belief networks (Aspinall et al. 2003) and frequency-based methods. Two SAC meetings were attended during the field seasons.

Additionally, extensive archival research was carried out at the Montserrat Volcano Observatory; and using records from the UK government, both the Department for International Development (formerly the Overseas Development Agency) and the Office for Science and Technology. This included the risk assessments carried out on the volcano between 1995 and 2010.

\section{Results \\ Demographic (survey data)}

The majority of respondents were from Anglophone countries, with a significant number from Europe (the questionnaire was only distributed in English). Nationalities were recorded into two categorical variables. The first denoted countries with and without active volcanoes. The second took the countries with volcanoes and divided them into 'wealthy' and 'poor' to measure the impact of resources on responses to the questions. 'Poor' countries were identified as those considered such by the International Monetary Fund.

There was a strong correlation between highest position at an observatory and level of highest degree $(\rho=0.248, p=0.001)$, and between highest position at observatory and experience in decision making $(\rho=0.547, p=0.000)$. This meant that these variables had to be used carefully to avoid multicollinearity. It also suggests that those employed in observatories at the higher levels are in general highly educated and have research experience. It also implies that many of those with higher degrees who completed the questionnaire had observatory 
experience. This represents a possible bias in the demographic. It should also be noted that there were roughly twice as many men as women in the group.

Some of the tests for this analysis involved ranking the data. The 'highest position at observatory' (Table 2 b) category was used for two separate assessments. Firstly, it was used to gauge observatory experience, and being 'affiliated' to an observatory was taken as the third category, with technicians and volunteers following this. Secondly, it was taken as a proxy for academic as opposed to observatory focus, and for this technicians and volunteers were counted above 'affiliated' personnel. This is a somewhat crude distinction, and forms a very small part of the overall analysis. It does however point to a few distinctions in the final section of the paper.

Table 2 Gives frequency data for several different demographic variables used in the survey, summarised for clarity

\begin{tabular}{|l|l|}
\hline Nationality of respondents & $\%$ of respondents \\
\hline USA & 30.1 \\
\hline UK & 21.5 \\
\hline France & 12.2 \\
\hline Italy & 8.8 \\
\hline Germany & 5.5 \\
\hline New Zealand & 4.1 \\
\hline Canada & 2.8 \\
\hline South American countries & 3.6 \\
\hline Other Europe & 8.4 \\
\hline Australia & 1.1 \\
\hline Philippines & 0.5 \\
\hline No response to this question & 1.4 \\
\hline Highest position at an observatory & \\
\hline Chief scientist & 6.3 \\
\hline Scientist & 27.0 \\
\hline Technician & 2.6 \\
\hline Affiliated scientist & 12.2 \\
\hline Volunteer & 13.8 \\
\hline Other & 9.5 \\
\hline None & 19.0 \\
\hline Unknown & 5.8 \\
\hline Non-volcanologist & 3.2 \\
\hline Highest degree in geosciences & \\
\hline
\end{tabular}




\begin{tabular}{|l|l|}
\hline Ph.D & 52.9 \\
\hline Master's & 33.3 \\
\hline Bachelor's & 9.5 \\
\hline Diploma & 0.5 \\
\hline Other discipline (no degree in Geoscience) & 3.2 \\
\hline Geology & 22.8 \\
\hline Geophysics & 27.5 \\
\hline Geochemistry & 25.9 \\
\hline Earth sciences & 15.3 \\
\hline Risk analysis & 3.7 \\
\hline Other & 4.2 \\
\hline Respors
\end{tabular}

Respondents were asked for the subject of their highest degree. These varied and have been recorded primarily to distinguish geophysicists and geochemists. The Earth Sciences category was used for respondents who were not specific to this task, writing, for example, 'volcanology', which could be either geophysics or geochemistry or both

\section{Volcanologists' views on monitoring techniques}

The surveyed volcanologists were asked to rank from 1 (least useful) to 5 (very useful) a range of monitoring techniques, for both persistently and potentially active volcanoes. They were also asked for opinions on other technologies and on those rising in importance as research into them continue. This section presents a statistical analysis of questionnaire data concerning monitoring technologies and techniques, on both potentially and persistently active volcanoes. The mean ratings are shown in Fig. 2. 


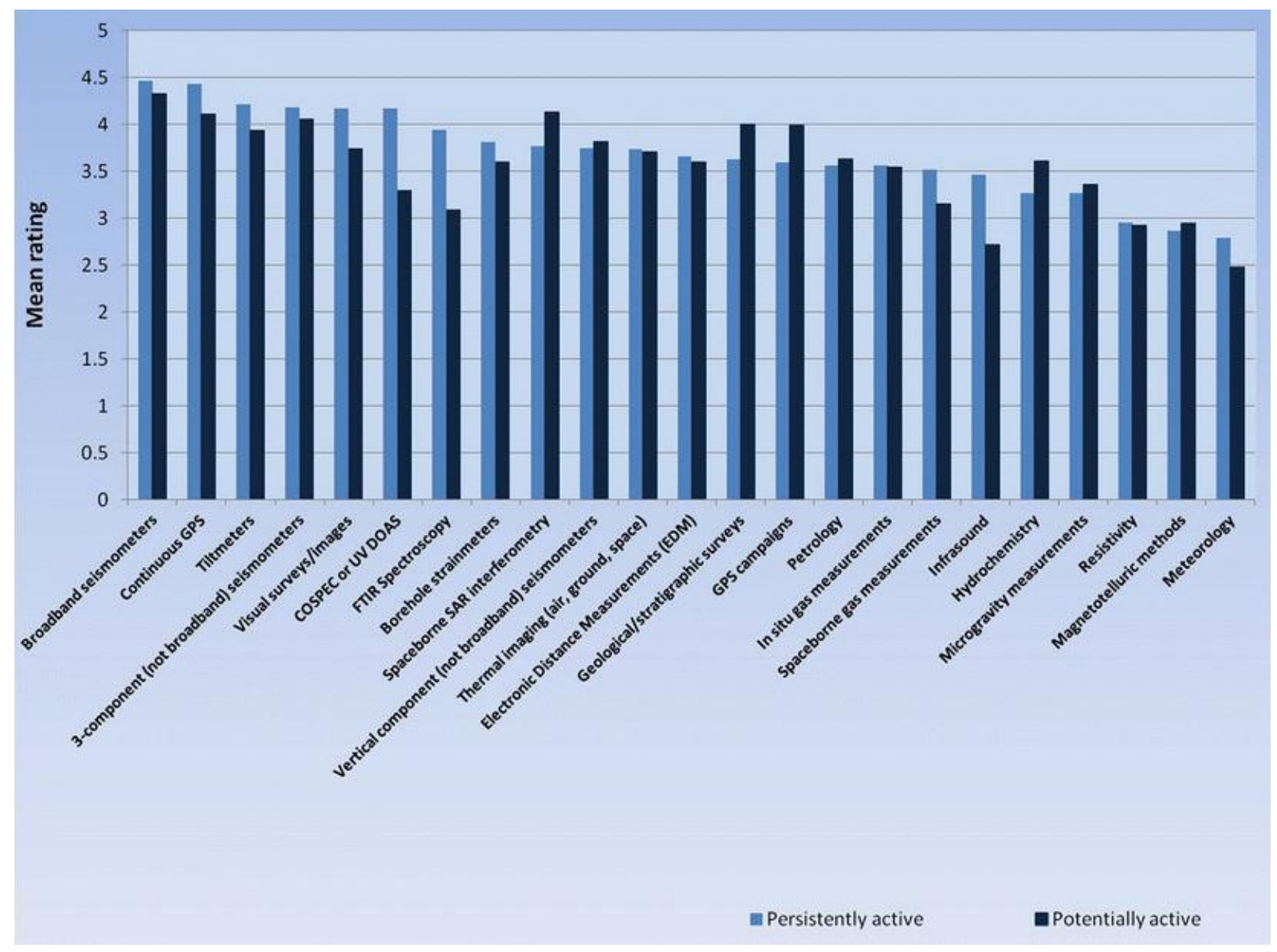

Fig. 2 Volcanologists' assessment of different monitoring technologies. Cronbach's alpha $=0.940$

Other demographic variables showed some significant associations within the data. All effects are reported at the 5\% significance level. Those with experience in decision making were less likely to think that visual signs at a persistently active volcano and tiltmeters at a potentially active volcano were of use $\left(\chi^{2}(4)=12.49,10.24\right)$ and more likely to rate petrological monitoring and correlation spectrometer (COSPEC)/DOAS-based gas measurements at a persistently active volcano $\left(\chi^{2}(4)=12.34,9.51\right)$. Of the ranked variables, those with higher degrees were more likely to rate highly COSPEC/DOAS measurements at persistently active volcanoes $(H=10.22, p<0.01)$, and gave lower ratings for infrasound $(H(3)=9.37$; $J=1419.0, z=-3.05, r=-0.28)$, FTIR $(H(3)=7.32 ; J=1,412, z=-2.62, r=-0.24)$ and resistivity $(H(3)=9.47 ; J=1,097, z=-2.93, r=-0.28)$ at potentially active volcanoes. Having more experience at observatories seemed to lower the approval of tiltmeters for potentially active volcanoes $(H(3)=18.12 ; J=4,258, z=-2.69, r=-0.22)$. There were no significant associations between specialism and rating.

Respondents were also asked to provide details of techniques not on the list. These are given in Table $\underline{3}$. Suggestions for technologies that are likely to be developed so that they can make a major contribution to monitoring are listed in Table 4.

Table 3 Suggested additions to the list of monitoring techniques 


\begin{tabular}{|c|c|c|}
\hline Technology & $\begin{array}{c}\text { No of mentions } \\
\text { (persistently active) }\end{array}$ & $\begin{array}{c}\text { No of mentions } \\
\text { (potentially active) }\end{array}$ \\
\hline $\begin{array}{l}\text { Lahar monitoring (e.g. acoustic flow } \\
\text { metres) }\end{array}$ & 1 & 0 \\
\hline Doppler radar & 5 & 0 \\
\hline Photography & 2 & 0 \\
\hline Spaceborne radar & 1 & 0 \\
\hline Magnetic field monitoring & 1 & 0 \\
\hline Ash leachates & 1 & 0 \\
\hline Flyspec (identical to DOAS, above) & 2 & 1 \\
\hline SO2 camera & 2 & 1 \\
\hline airborne Licor for $\mathrm{CO} 2$ & 1 & 1 \\
\hline Soil gas & 4 & 3 \\
\hline Daily tephra sampling & 3 & 0 \\
\hline Continuous webcams & 4 & 1 \\
\hline EM survey & 1 & 0 \\
\hline Lightning detection & 1 & 1 \\
\hline Local observers & 3 & 0 \\
\hline Eruptive history & 1 & 0 \\
\hline Self-potential & 3 & 2 \\
\hline $\mathrm{C} / \mathrm{S}$ ratio & 1 & 0 \\
\hline Chemical sensors (SO2, H2S, CO2) & 2 & 1 \\
\hline Historical records/population surveys & 2 & 0 \\
\hline Crater lake calorimetry & 1 & 0 \\
\hline Ground penetrating radar & 1 & 2 \\
\hline Lava flux & 1 & 0 \\
\hline Geochronology & 1 & 2 \\
\hline Radon surveys & 1 & 0 \\
\hline Core drilling boreholes & 2 & 2 \\
\hline High resolution video & 2 & 0 \\
\hline 3-Component borehole seismometers & 1 & 1 \\
\hline Seismic tomography & 1 & 1 \\
\hline Precise levelling & 1 & 0 \\
\hline Dry tilt & 1 & 1 \\
\hline hydrogeology & 1 & 1 \\
\hline Structural survey & 0 & 1 \\
\hline $\begin{array}{l}\text { Spring discharge monitoring (proxy for } \\
\text { volumetric strain) }\end{array}$ & 0 & 1 \\
\hline
\end{tabular}




\begin{tabular}{|l|l|l|}
\hline Technology & $\begin{array}{c}\text { No of mentions } \\
\text { (persistently active) }\end{array}$ & $\begin{array}{c}\text { No of mentions } \\
\text { (potentially active) }\end{array}$ \\
\hline Radar & 0 & 1 \\
\hline $\begin{array}{l}\text { Numerical models to forecast lava flows } \\
\text { and ashfall }\end{array}$ & 0 & 1 \\
\hline $\begin{array}{l}\text { Dendrochronology/lichenometry } \\
\text { dating/duration }\end{array}$ & 0 & 1 \\
\hline $\begin{array}{l}\text { Continuous monitoring of areal gas } \\
\text { diffusion }\end{array}$ & 0 & 1 \\
\hline $\begin{array}{l}\text { Hydro-acoustic measurements for crater } \\
\text { lakes }\end{array}$ & 0 & 1 \\
\hline Glaciology & 0 & 1 \\
\hline Petrological ratemeters & 0 & 1 \\
\hline
\end{tabular}

Table 4 Suggested future breakthroughs

\begin{tabular}{|l|l|}
\hline Technology & $\begin{array}{l}\text { No. } \\
\text { mentions }\end{array}$ \\
\hline Continuous multi-gas spectrometers & 8 \\
\hline $\begin{array}{l}\text { Affordable, robust hybrids of broadband seismometers and volumetric } \\
\text { strainmeters }\end{array}$ & 1 \\
\hline Borehole dilatometers & 3 \\
\hline FTIR & 2 \\
\hline Continuous gravity & 1 \\
\hline CO2 detection methods & 1 \\
\hline InSAR & 7 \\
\hline Proliferation of webcams & 1 \\
\hline Miniaturised gas sensors & 1 \\
\hline $\begin{array}{l}\text { Artificial intelligence approach to data processing and analysis-warning } \\
\text { systems }\end{array}$ & 1 \\
\hline Real time kinematics & 1 \\
\hline Meteosat & 1 \\
\hline MODIS & 1 \\
\hline Infrasound & 1 \\
\hline UV cameras & 1 \\
\hline IR cameras & 1 \\
\hline Ground-based EM surveys & 1 \\
\hline C/S ratio & 1 \\
\hline Ocean noise volcano tomography & 1 \\
\hline Low temperature, high spatial and temporal resolution TIR monitoring & 1 \\
\hline
\end{tabular}




\begin{tabular}{|l|l|}
\hline Technology & $\begin{array}{l}\text { No. } \\
\text { mentions }\end{array}$ \\
\hline Near real time analysis of shear splitting and seismic anisotrophy & 2 \\
\hline Deep well drilling & 1 \\
\hline Broadband seismology and local/regional stress models & 1 \\
\hline Continuous ground deformation modelling & 1 \\
\hline microgravity & 2 \\
\hline Lahar detection & 1 \\
\hline Telemetry improvements & 2 \\
\hline Ground-penetrating radar & 1 \\
\hline Doppler radar & 2 \\
\hline Improved numerical models & 2 \\
\hline 4D seismic methods & 2 \\
\hline Seismic-acoustic arrays & 1 \\
\hline Satellite imagery & 3 \\
\hline Local knowledge accreditation & 1 \\
\hline Differential GPS & 1 \\
\hline Handheld XRF & 1 \\
\hline Harmonic tremor studies & 2 \\
\hline Airborne magnetic & 1 \\
\hline Multidisciplinary networks & 3 \\
\hline LIDAR & 1 \\
\hline
\end{tabular}

A number of comments were made regarding likely future breakthroughs. One concern was cost-effectiveness: it was noted that many of the techniques might provide very interesting information about the volcano, but the relevance of that information to hazard assessment and population management might not merit the expense and would not survive cost-benefit analyses. Another key question concerns the 'fundamentals': many respondents stated that they assumed that the baseline was being covered already - both in terms of basic monitoring, and historical/geological local knowledge. New technologies were considered to have a role once the 'fundamental studies' were completed — and the political challenge of getting sufficient baseline surveys and systems in place at an apparently quiet volcano was also noted. Taking this a step further, respondents suggested that new technologies should be deployed once the volcano becomes active, to gain further information: relatively basic systems can be installed on quiet volcanoes to ensure that the onset of unrest is identified. This is more costeffective, and therefore easier to justify. An important aspect of justifying resources was the consultation of references and past eruptive experiences: the technological history.

A further set of comments dealt with the connection of monitoring data to physical models, and the advanced stages of data processing and interpretation. This was linked to, for example, better understandings of seismic 'noise', the elastodynamics of the crust, fluid transport models, artificial intelligence in continuous data stream analysis, and models that 
incorporate multidisciplinary techniques. The potential usefulness of satellites in thermal, ash and gas detection was a further recurring theme.

\section{Volcanologists' views on risk management Science at the policy interface}

The third section of the questionnaire asked scientists to rate the importance of particular types of experience and communication. This section of the paper thus examines the interaction of scientists with local officials and the public, in the context of monitoring volcanoes and managing the social implications of volcanic activity.

\section{Scientists and local officials}

There were two subsections in this part of the survey. The first section examined the interaction between scientists and local officials in volcanic emergencies - both crises and persistently active volcanoes. It asked scientists to rank from 1 to 5 the importance of specific interactions. Tests were carried out to ascertain whether or not the predictor variables had a significant effect on the results. It was concluded that level of degree and specialism did not affect the results, but those with experience in decision making rated cooperation with local authorities $(U=3,079, z=-2.19)$, local politicians $(U=2,829, z=-2.20)$, media $(U=2,822$, $z=-2.73)$ and religious leaders $(U=2,394, z=-3.09)$ as less important in managing persistent eruptions than did those who lacked the experience. This was also true for religious leaders at potentially active volcanoes $(U=2,473, z=-2.41)$ - but it should be noted that this is a highly culturally dependent question, and may have been influenced significantly by the fact that the survey was in English and many respondents were from countries where religion may not be perceived as important. (Other authors have discussed the importance of religion in managing volcanic disasters; e.g. Chester 2005; Donovan 2009.) Those who lived in countries with active volcanoes, however, while generally regarding religious leaders as relatively unimportant $(U=2,626, z=-2.61)$, also felt that communication and trust between scientists at persistently active volcanoes $(U=3,168, z=-2.37 ; U=2,856, z=-2.32)$ was not as important as those without active volcanoes. Trust between scientists was also viewed as less important at potentially active volcanoes $(U=2,702, z=-2.27)$. Of the multi-group variables, observatory experience had surprisingly little impact on the results. The only significant value was $H(4)=9.34, p<0.05$, suggesting that observatory experience had some effect on the importance ascribed to scientific consensus in a crisis.

The frequencies data suggest:

- Long-term relations with local authorities was more important in a long-term eruption than a crisis; all other variables were more important in a crisis, but had higher standard deviations in the long-term scenario. This may suggest a level of uncertainty among the respondents.

- In a crisis, communication between scientists and cooperation of local authorities were the most important ( $x=4.76,4.75$ respectively, with low standard deviations). Consensus between scientists was not regarded as unequivocally fundamental $(x=3.81, s=1.01)$.

A factor analysis was carried out on these data to look at correlations between the variables in greater depth. The factors identified and their weighting - how much of the variance in the dataset that is explained by each factor-is given in Table 5. Tables 6 and 7 show the rotated components for each statement - how the factors were distributed. 
Table 5 Factors identified, Cronbach's alpha $=0.893$

\begin{tabular}{|l|l|l|}
\hline Factor & Eigenvalue & $\%$ Variance \\
\hline High-level interaction & 6.85 & 42.80 \\
\hline Communication by local bodies & 2.46 & 15.35 \\
\hline Scientific discussion & 1.42 & 8.88 \\
\hline Total variance & & 67.02 \\
\hline
\end{tabular}

Table 6 Rotated components for volcanic crisis scenario

\begin{tabular}{|l|c|r|r|}
\hline How would you rate the importance of the following in a volcanic crisis? & $\mathbf{1}$ & $\mathbf{2}$ & $\mathbf{3}$ \\
\hline Communication between scientists & 0.77 & 0.37 \\
\hline Consensus between scientists & 0.13 & 0.24 & 0.79 \\
\hline Trust between scientists & 0.63 & 0.46 \\
\hline Cooperation of local authorities & 0.79 & 0.16 & 0.16 \\
\hline Long-term relationship with local authorities & 0.70 & 0.21 & 0.11 \\
\hline Role of local political leaders & 0.27 & 0.74 & 0.09 \\
\hline Role of local religious leaders & 0.004 & 0.85 & 0.06 \\
\hline Communication using the media & 0.63 & 0.48 & 0.09 \\
\hline
\end{tabular}

Numbers 1-3 refer to factors in Table 5

Table 7 Rotated components for persistently active volcano scenario

\begin{tabular}{|l|c|c|c|}
\hline $\begin{array}{l}\text { How would you rate the importance of the following at a persistently } \\
\text { active volcano? }\end{array}$ & $\mathbf{1}$ & $\mathbf{3}$ \\
\hline Communication between scientists & 0.70 & 0.08 & 0.38 \\
\hline Consensus between scientists & 0.16 & 0.25 & 0.83 \\
\hline Trust between scientists & 0.69 & & 0.41 \\
\hline Cooperation of local authorities & 0.82 & 0.21 & \\
\hline Long-term relationship with local authorities & 0.83 & 0.22 & \\
\hline Role of local political leaders & 0.22 & 0.77 & 0.20 \\
\hline Role of local religious leaders & 0.04 & 0.87 & 0.16 \\
\hline Communication using the media & 0.55 & 0.41 & 0.09 \\
\hline
\end{tabular}

Numbers $1-3$ refer to factors in Table 5

The results suggest that while scientific consensus and discussion are valued highly, the question of local authorities is the cause of most concern for the respondents. This is indicative of the problems of transdisciplinary communication, and the position of scientists more generally in an age of increasing scientific input into governance. It also reflects the lack of control that scientists have over the dissemination of information by locally recognised institutions such as the media. While determining the message in cooperation with other scientists and local authorities is the most significant factor, there is also concern about the way that that message is conveyed. Scientific discussion is also important, but is less of a concern, perhaps because it is relatively familiar territory for scientists. 


\section{Scientists and social awareness}

The second subsection enquired about the particular knowledge and experiences of the scientist. The only predictor that affected this dataset was whether or not the volcanologist was born in a volcanic country - those who were felt that observatory experience elsewhere was less important for managing a persistently active volcano $(U=2,922, z=-2.03)$. In this analysis, four factors were identified (Table 8). The components are given in Tables 9 and 10 .

Table 8 Factors identified, Cronbach's alpha $=0.799$

\begin{tabular}{|l|l|l|}
\hline Factor & Eigenvalue & \% Variance \\
\hline Monitoring/volcano management experience & 4.27 & 35.60 \\
\hline Local/political knowledge & 2.26 & 18.85 \\
\hline Cultural awareness & 1.46 & 12.16 \\
\hline Academic experience & 1.11 & 9.23 \\
\hline Total variance & & 75.84 \\
\hline
\end{tabular}

Table 9 Rotated components for volcanic crisis scenario

\begin{tabular}{|l|c|c|c|c|}
\hline $\begin{array}{l}\text { How would you rate the importance, for a scientist, of the following } \\
\text { during a volcanic crisis? }\end{array}$ & $\mathbf{1}$ & $\mathbf{3}$ & $\mathbf{4}$ \\
\hline Local knowledge of the volcano & 0.21 & 0.88 & 0.10 & 0.09 \\
\hline Local knowledge of the population & 0.67 & 0.55 & 0.06 \\
\hline Local knowledge of religious beliefs and practices & 0.14 & 0.91 & \\
\hline $\begin{array}{l}\text { Experience in a volcanic crisis elsewhere } \\
\text { Long-term experience (>5 years) in an observatory monitoring an active } \\
\text { volcano elsewhere }\end{array}$ & 0.79 & 0.18 & 0.04 & 0.19 \\
\hline Academic experience as a volcanologist in a university & 0.09 & & 0.05 & \\
\hline
\end{tabular}

Numbers $1-4$ refer to components in Table 8

Table 10 Rotated components for persistently active volcano scenario

\begin{tabular}{|l|c|c|c|c|c|}
\hline $\begin{array}{l}\text { How would you rate the importance, for a scientist, of the following } \\
\text { during a long-term eruption? }\end{array}$ & $\mathbf{1}$ & $\mathbf{3}$ & $\mathbf{4}$ \\
\hline Local knowledge of the volcano & 0.30 & 0.80 & 0.04 & 0.01 \\
\hline Local knowledge of the population & 0.26 & 0.53 & 0.56 & \\
\hline Local knowledge of religious beliefs and practices & 0.11 & 0.03 & 0.94 & \\
\hline Experience in a volcanic crisis elsewhere & 0.80 & 0.09 & 0.06 & 0.05 \\
\hline $\begin{array}{l}\text { Long-term experience (>5 years) in an observatory monitoring an active } \\
\text { volcano elsewhere }\end{array}$ & 0.86 & 0.16 & 0.05 & 0.06 \\
\hline Academic experience as a volcanologist in a university & 0.11 & 0.07 & 0.88 \\
\hline
\end{tabular}

Numbers 1-4 refer to components in Table 8

The data suggest that the major control on responses in this section related to experience rather than academic knowledge about volcanoes. Again, this implies that volcanologists are concerned about the extra-scientific interactions as well as with monitoring experience, rather 
than research experience alone. Monitoring is a different type of activity from research, and it involves local knowledge of a particular volcano and learning the characteristic signals and warning signs, and this distinction is reflected in the responses to this question.

\section{Discussion}

The monitoring technologies currently rated highly for persistently active volcanoes are broadband seismometers and continuous GPS, followed closely by tiltmeters, COSPEC or UV DOAS, three-component seismometers and visual surveys/images. Meteorology, resistivity and magnetotelluric methods were the least regarded, but still valued as contributing some relevant information; however, meteorology may have been insufficiently specific, because it has multiple implications, such as monitoring ash cloud trajectories and also forecasting lahars or dome collapses. For potentially active volcanoes, InSAR and stratigraphic or geological surveys gained some importance, as did vertical component seismometers and GPS campaigns. Gas measurements, interestingly, lost importance considerably.

The most likely breakthroughs may be summarised as follows:

- InSAR and continuous measurements of gas species such as $\mathrm{HCl}, \mathrm{HF}$ and $\mathrm{H}_{2} \mathrm{~S}$ are regarded as the most likely breakthrough technologies for monitoring volcanoes in the next few years.

- Infrasound and ground- or airborne radar techniques are also identified as likely contenders, as are detailed analyses of seismic signals (shear wave splitting, harmonic tremor), using new models and more precise instruments.

- Multidisciplinary techniques are also mentioned, particularly geophysical hybrid instruments involving seismic, ground deformation, strain or infrasonic measurements. However, other respondents noted the importance of linking geophysical techniques with geochemical data using integrative software.

- Remote sensing is regarded as having significant potential, especially for monitoring potentially active volcanoes.

- A number of respondents, particularly those who have worked as volunteers at observatories (rather than as scientists) mentioned local knowledge and historical information as important.

- Improvement in numerical modelling was mentioned by several respondents in the comments.

The comments made by the scientists also reflect the diversity in starting points: some respondents considered hazard assessment and social scientific information as part of the monitoring process, while others dealt more closely with the science. This reflects a fundamental uncertainty in the current self-definition of volcanology: What is the role of the social sciences, and are they part of 'volcanology'? The concern for local populations will be discussed further below; the main point to note here is that scientists are interested in the wider context in which they operate and the social implications of their work. There is also the question of 'disciplinarity'.

From the scientific point of view, it is clear that there are significant differences between monitoring a persistently active volcano, and one that is currently dormant. For a dormant volcano, there was more emphasis on longer-term projects such as stratigraphy/geological 
mapping, petrology, GPS campaigns, spaceborne monitoring and geophysical techniques such as self-potential, magnetotelluric methods and microgravity, which have shown their value in the research context but are not considered fundamentally important for hazard management in the short-term. For both situations, however, seismometers and ground deformation monitoring are considered the most important monitoring methods, with application to persistently active volcanoes also scoring high for gas spectrometry. Gas sampling and hydrochemistry are preferred for potentially active volcanoes, in the absence of a significant plume. Visual monitoring is also considered of prime importance, particularly at persistently active volcanoes.

\section{Technologies and mobility}

The timescale of new technological advancements in volcano monitoring was commented on by several interviewees, and survey respondents. A pertinent example is the use of spectroscopic gas measurements in eruption prediction. In the early years of the eruption on Montserrat, a COSPEC was purchased to monitor the $\mathrm{SO}_{2}$ flux (funded through an 'urgency' grant application to the UK NERC). $\mathrm{SO}_{2}$ increase has long been recognised as a key indicator of rising magma, resulting from the exsolution of $\mathrm{SO}_{2}$ as pressure decreases. On Montserrat, a spectrometer owned by the USGS had initially detected very high levels of $\mathrm{SO}_{2}$ (several thousand tonnes per day), and this caused concern. The sustained high level of $\mathrm{SO}_{2}$ emissions during the first pause in magma extrusion (March 1998 to November 1999) was an indicator that basalt influx at depth was ongoing (Oppenheimer et al. 2002). At the same time, spectroscopic measurements of atmospheric $\mathrm{SO}_{2}$ are fraught with high errors, due to wind speed inaccuracies, imperfect algorithms for correcting atmospheric effects, the potential for shallow sealing and/or temporary storage of gas, and changes in the plumbing system at depth (e.g. Kern 2010). This renders short-term prediction based on $\mathrm{SO}_{2}$ variations unreliable, particularly where a single spectrometer is used, although ongoing high $\mathrm{SO}_{2}$ emissions can be diagnostic of an active system, and on Montserrat during the first pause in the eruption, elevated $\mathrm{SO}_{2}$ levels led to individual scientists being concerned that the eruption was not over (Oppenheimer et al. 2002; Sparks 2003). Seismicity, however, can be a very good short-term predictor, but in recent years has become less reliable than it had been early in the eruption. Broadband seismic networks are very reliable and highly valued by scientists, as demonstrated above. One interviewee suggested that the use of DOAS instrument arrays (e.g. Burton et al. 2007) is the equivalent of the broadband seismometer array 15 years ago: it has great potential for further development as processing improves.

The development and testing of new technologies requires dialogue between the research and monitoring communities, and may also involve interaction with industrial and commercial organisations to identify appropriate and affordable products. There has to be a commitment to the value of the information to be obtained from the technology, and a justification for spending public money on it. In general, research money is spent developing and testing the method, and then if it is successful, it may be deployed for monitoring purposes. However, from a practical perspective, certain technologies may remain beyond the scope of observatory work, and external advice from expert consultants may be required. Petrological monitoring, for example, may be contracted out, as has occurred during the eruption of the Soufriere Hills Volcano on Montserrat. This situation may present a number of challenges, not least in assessing hazard-relevant information, which may be a matter of subjective judgement rather than solid procedures, and hence includes the potential for increased uncertainty. 


\section{Uncertainties and errors, and the challenge of combining different kinds of knowledge}

Science meetings in volcano observatories are generally highly interdisciplinary, involving geophysicists, seismologists, geochemists, petrologists and others. The information that they bring to the meeting is combined in assessing the state of the volcano, and involves crossdisciplinary communication and expertise: at least one person in the room has to be able to understand and evaluate the evidence that is presented. Collins (2004) discusses the idea of 'interactional expertise': having the ability to communicate meaningfully within a discipline. This is not the same as 'contributory expertise', which is expertise that allows one to make a substantive contribution to the progression of the discipline - the contribution of new research. Interactional expertise is that required of observatory directors, for example, in making judgements in the face of uncertain evidence of different types and potentially with contradictory implications. There are several complexities in this, not least the definition of acceptable or typical error. Thus a gas scientist looking at GPS data may interpret the margin of error differently from a geodesist. Similarly, different scientists may have varied ideas about the importance of particular types of information. This points towards the importance of discussion as a part of scientific process when public safety is at stake.

The social context of scientific discussion thus becomes important. One member of the Montserrat Scientific Advisory Committee noted that the specificity of the Montserrat situation allowed 'this somewhat different... mode of scientific discussion, that's less reliant on wider more academic perspectives, and much more on interpreting frequently changing operational datasets... the one aspect ... that I find the hardest to bring to bear is knowing when to bring in... other perspectives and scientific topics':

...there's the issue of the groundwater, there's the issue of stratigraphy, and the capability of plinians, there are issues about the gas - the significance of the gas signals - there's the issue of the longer term modelling of the reservoir and so on-all of which are relevant to the argument but are very hard to bring in a focussed manner.... Do you try to squeeze more time out of the members of the SAC [Scientific Advisory Committee], or do you broaden the network of expertise which you feed into the SAC... and it's not obvious which would be the best way to go about it. I'm sure if we were to say to the [UK] Foreign Office, you need to double the resources you're putting into this, they'd say, "Why? You've been getting along fine." Senior scientist.

There are many possibilities for research and collaboration within volcanology. At observatories and within the context of scientific advice more widely, difficult choices have to be made not only about which techniques to use in monitoring, but also in what questions to concentrate on. A strength of the Montserrat situation is that the presence of both the Montserrat Volcano Observatory and the Scientific Advisory Committee, which consists of five highly experienced volcanologists, brings together multiple knowledges. Multiple disciplines are represented, but so are multiple experiences, histories and expertises - not purely academic science, but firmly grounded in it. Another important aspect is that of peripheral research - collaborations with outside scientists in order to investigate some of the questions noted above. However, much of this is research-sourced and academically based. Unfortunately, observatories may not have time to coordinate and initiate such research, particularly in the developing world. 
The importance of individuals in the transfer and movement of technologies that are on the threshold between monitoring and research is considerable. For example, the FLAME network on Mount Etna for monitoring $\mathrm{SO}_{2}$ emissions has been introduced and maintained by a few individuals (e.g. Burton et al. 2009). Similarly, the infrasound network on Montserrat, and that on Stromboli, have been instigated by small groups of people and via individual connections (Ripepe et al. 2010). The results are then communicated through the peer-review process, and at conferences and workshops. Interest in the development and communication of monitoring techniques through these media is increasing, as demonstrated by recent conference sessions, but there are always financial constraints on observatories, not to mention the manpower requirements and the processing and interpretation time.

The integration of multiple monitoring methods has several effects on uncertainty: it can decrease epistemic uncertainty (that due to lack of knowledge, as opposed to aleatory uncertainty, which is due to the randomness of the nature system and is irreducible). However, if the results of different techniques are apparently contradictory, then the epistemic uncertainty is increased and so is the level of trust that can be placed in the monitoring method in the first place. The management of these uncertainties, and the danger of multiplying errors, is a feature of monitoring volcanoes. It is in this context that expert judgement has to be used to obtain the information necessary to provide authorities with assessments. Again, there are two sides - the more opinions, the better, but this makes agreement more difficult to reach. Interviews with scientists involved on Montserrat, and the data presented above, suggest that there is a balance to be achieved between local knowledge, experience of crisis management both in the location and elsewhere, and academic expertise, not to mention different disciplines ranging from physical to social sciences. The fact that scientific consensus was viewed as less important than communication between scientists also emphasises the importance of discussion between a range of views, over a polarised approach. This suggests that methods such as structured expert elicitation (Aspinall et al 2002; Aspinall 2006, 2010) are an important step in assessing volcanic risk quantitatively.

Uptake of new technologies and methods depends on a number of different factors, relating not only to their scientific merit but also to social, economic and political factors. These include scientific networks, interactions between individual scientists, local knowledge about the volcano, financial considerations and justifiability to non-scientists: 'in order to get it done you need to show how it can work in an operational environment' (Senior scientist). While a technology may provide information about the volcanic system that is of great interest in scientific research, progression into the monitoring environment requires demonstrable potential to be of use to society. This carries with it some dangers, too, since science has to be translated to explain the value to society, and the simplification inherent in this process can lead to misunderstandings - particularly where local officials have high and unrealistic expectations about scientists' ability to forecast information. Challenges for new observatories may include explaining the need for networks of instruments, and that for more than one monitoring method, for example. The challenge of demonstrating cost-effectiveness for volcano monitoring beyond the volcanological community can be significant.

One problem with the justification of monitoring technologies is that of standardisation: many factors influence the form of monitoring networks, such as topography and access, the type of volcanism, location of populations, and likely hazards. Many scientists regard the standardisation of monitoring networks and systems with suspicion: 
There's been a lot of debate whether or not to do that, and they've rejected it, feeling that every volcano is a little bit different, and you've got to be flexible and rigorous. Senior scientist.

Thus, judgement calls have to be made by scientists on the ground, and then explained to local officials. While researchers make judgements based on future directions of interest, observatories have to look for functionality, reliability and relevance to hazard and risk assessment. There may also be cultural factors involved - one factor that featured heavily in MVO's early years was the desire to interface with the regional seismic network (Aspinall et al. 2002), and this was important to both scientists and local stakeholders with political motives. Observatories stand between the research community on the one hand, and the public on the other. Managing this middle-ground position requires particular skills, and these are not necessarily the same skills that are developed through academic experience alone (Collins and Evans 2007).

Interactional expertise is a useful concept for observatories because they require multidisciplinary assessments to be made - thus at least one scientist must be able to engage with all of the represented disciplines. This does not simply mean understanding the data, but also having some knowledge of the way that particular disciplines analyse their data - which may or may not be sufficient knowledge to make a contribution to the field at a research level. The distinction was described by one senior scientist:

It's a lot of work you have to put in cos otherwise you know a bit of everything without actually mastering anything ... I can do research on it at a reasonable level but I wouldn't actually be making the technique evolve or the science really evolve-I don't want to be part of the research in that area, I just want to be able to use it... it's a lot of extra work but it's very fulfilling ... and actually I found that particularly useful if you come to work in an observatory where monitoring is multidisciplinary, so you are able to understand the gas data quite well, able to understand the deformation stuff, and seismology as well.

One local official commented, 'it's like a jigsaw and you've got a picture from the geologist and a piece from the seismologist and a picture from a volcanologist, and you start slotting them together': the process of slotting them together involves focussing on the final product. This situation is complicated by a variety of human traits, not least overconfidence:

We both agree that one of the chief lessons of the role of scientists in these long drawn-out states of unrest is that the scientists get over-confident in their predictions, and the population becomes increasingly risk-immune.... and both sides do persuade themselves - reaffirm one another's delusions, really. Senior scientist

Gibbons et al. (1994) make a distinction between mode-1 science (based on research progression alone - 'traditional' science) and mode-2 science, which is application-driven. While researchers increasingly have to demonstrate the social relevance of their work, this is generally worked out after the research plan is drawn up, while monitoring organisations have to plan their requests according to their social mission. Within volcanology, however, this distinction is not clear-cut, because of the nature of volcanism - and therefore the role of field stations in data generation and centralisation. It is nevertheless helpful in understanding the role of science when it comes into contact with policymaking and shifts in emphasis.

\section{Expertise and experience}


The relative merits of expertise and experience take on a geographical aspect in assessing volcanic hazard: the value and importance of local knowledge are contested and controversial in volcanology, as scientists discuss whether or not apparently similar volcanoes can be compared. This is a consideration in developing alert levels that cover multiple locations, and in transferring expertise between observatories and disaster managers. Scientists interviewed in this project suggested that local knowledge is important, but sometimes objectivity can be increased by the involvement of scientists without experience of a particular volcanic system. This is a very important question for governments setting up advisory structures for volcanic hazard and risk policymaking. In the survey, the respondents emphasised the importance of monitoring and observatory experience, and this is consistent with interviewee comments. While local knowledge and experience were considered to be desirable in many situations, their enhancement with input from people outside of the situation was encouraged because 'I can't see how objective one can be if after a while you've been around on the ground interfacing with the activity for so long that you must be influenced in a way that might be good or might be bad': there was a fear that too much time in one place immunised scientists from seeing the bigger picture. At the same time, being 'on the ground' was also identified as an important qualification - being able to see, hear and indeed smell the volcano (not to mention touch and, if spending too much time eating outside, inadvertently taste it) clearly improves both sympathy with the local political and social situation and an attuned awareness of the physical processes involved.

In a long-term eruption, particularly, the danger of scientific assessments stagnating, or tending towards a constant thought pattern or even model, increases: 'it cuts both ways... your independence and objective assessment of the situation must be influenced by your experience.' This is positive if experience makes one better able to assess the volcanic activity, but negative if one tends to assume that patterns will be repeated without considering the uncertainty. Missing something because it has always been there becomes a danger: 'we need a balance between the experience and the experience-of-Montserrat'. Discussion with the wider academic community, too, both through advisory structures and through conferences and meetings, was identified as helpful, although also the source of some tensions - and also demonstrative of the different types of working involved - researchdominated rather than monitoring-dominated, in the simplest formulation. Academic experience was regarded as less important than experience in monitoring and local knowledge, but was nevertheless valued, especially where interaction with the academic community stimulated new ideas and a broader view of the possibilities. Discussion - with as broad a group as possible - was agreed to be a fundamentally important aspect of hazard and risk assessment, but requires the presence of skilled facilitators to ensure that the discussion is not dominated by a single person. In this context, statistical techniques such as expert elicitation may also be used (Aspinall 2006, 2010) to provide quantitative results. Lindsay et al. (2010) took this a step further and used expert advice to set the rules for the BET_EF code prior to a simulated eruption.

Scientific advisory practices vary around the world, and may be extremely complex in a volcanic crisis - particularly where the hazards transcend national boundaries. The management and communication of scientific uncertainty may be compounded by social factors within and beyond the scientific community. In addition, disagreement between scientists can complicate already highly pressured environments. In policymaking, the precautionary principle is often advocated in the governance of uncertainty; but in the case of low-probability risks, decisions can be costly. 


\section{Conclusions}

A survey of volcanologists carried out in 2008-2009 suggests that participants regard broadband seismometers as the most useful tool in monitoring volcanoes, but with continuous GPS measurements a very close second. Other important techniques included tiltmeters, visual surveys and gas spectroscopy. Multi-gas instruments and satellite radar interferometry were thought to be likely future monitoring breakthroughs. The importance of processing algorithms and their development, particularly in seismic data analysis, was also mentioned by a number of respondents.

The relative importance of expertise and experience-much discussed in Science Studies literature (e.g. Collins and Evans 2002; Wynne 2003; Jasanoff 2003a, b) —in managing an eruption, either on persistently or potentially active volcanoes, was not straightforward. However, the factor analysis suggests that practical experience was rated more highly than academic experience - and local knowledge of the volcano was particularly important. During eruptions, it was felt that communication between scientists, and the cooperation of local authorities, were the most important of the options during a crisis, but long-term relationship with the authorities was more important on a persistently active volcano. Communication and trust between scientists were generally considered more important than consensus. The role of the media was recognised as significant too, particularly in a crisis. The multidisciplinarity inherent in volcanology means that communication between disciplines can be an issue, and requires scientists with interactional expertise. Ideally, this includes an awareness of the uncertainties associated with different types of information. Social scientific analyses within the scientific advisory process could facilitate the development of scientific advice and its framing within the political context.

Acknowledgements AD acknowledges a NERC-ESRC PhD studentship. The authors thank three anonymous reviewers for their helpful comments, which improved the quality of the manuscript. The people of Montserrat, the staff of the MVO and the members of the SAC are thanked for their support and insights.

\section{Appendix \\ Preliminary tests}

Initial exploration of the survey dataset was carried out to ascertain which parts were normally distributed (parametric tests are only appropriate for normally distributed datasets). Initially, histograms were examined for each variable (i.e. each question), and the skewness and kurtosis were calculated. These were rated as significant for the 5\% level at $z=1.96$ or greater (Field 2000). Kolmogorov-Smirnov and Shapiro-Wilk tests were carried out to compare the data to a normal distribution, and 5\% significance was used to identify nonnormally distributed datasets. Homogeneity of variance was assessed using Levene's statistic, which looks for equal variances - an assumption of many parametric tests.

\section{$T$ tests}

$T$ tests are used to compare two means. They may be used either with different groups of participants (independent $t$ test), or with the same group (dependent $t$ test). It is the latter that have been used in this paper, since the same group of volcanologists answered all the questions, and these are discussed below. $T$ tests are based on the null hypothesis that there is no systematic variation between the participants. The equation for the dependent $t$ test is then 
$t=D-\mu_{-} D /\left(s_{-} D / \sqrt{ } N\right)$

where, $D$ is the mean difference between samples, $\mu D$ is the difference expected assuming the null hypothesis, $s D$ is the standard deviation and $N$ is the number of samples. Dividing the standard deviations by the root of the number of samples calculates the estimated standard error. The $t$ test thus measures the systematic variation in the samples relative to the unsystematic variation, therefore testing the model.

\section{The $z$ score and effect size}

The $z$ score is a way of approximating the normal distribution so that the deviations from the mean can be compared:

$z=(\mathrm{X}-\bar{X}) / \mathrm{s}$

where, $X$ is a data point, $\bar{X}$ is the mean of the population, and $s$ is the standard deviation of the population.

The effect size, $r$, is calculated from the $\mathrm{t}$ statistic and the degrees of freedom:

$\tau=\left(t^{2} /\left(t^{2}+d f\right)=z / \sqrt{ } N\right.$

where, $t$ is the $t$ statistic, $d f$ is the number of degrees of freedom, $z$ is the $z$ score and $N$ is the number of samples. A small effect is defined as $r>0.1$, and a large one by $r>0.5$ (Field 2000).

\section{Non-parametric tests}

Data that were not normally distributed - largely those that reflected strong opinions-were tested according to a variety of non-parametric methods. The Mann-Whitney test is similar to the independent $t$ test and compares the median between two groups. It is thus only used for comparing two groups of data, but can be used as a test for the results of a Kruskal-Wallis test, in order to apply the Bonferroni correction (using a significance value of $0.05 /$ number of tests). It is denoted here by ' $U$ '. The Kruskal-Wallis test, denoted by ' $H$ ', is the nonparametric equivalent of the Analysis of Variance-it compares the medians of several groups.

$$
H=\frac{\left(\frac{12}{N(N+1)}\right) \sum_{i=1}^{k} R_{i}^{2}}{n_{i}}-3(N+1)
$$

Here, $R$ is the sum of ranks for each group, $N$ is the total sample size and $n$ is the sample size of a particular group. The Jonckeheere-Terpstra test for trends takes the analysis a step further, looking for trends within the ranked medians. It has been used where the groups are likely to impact the ordering of medians, and a value greater than 1.65 is considered significant (one tailed). 
Spearman's $\rho$ is a non-parametric correlation that works by ranking the data and then applying the equation for Pearson's correlation coefficient, $R$.

$$
R=\operatorname{cov}_{x y} / s_{x} s_{y}=\Sigma(\mathrm{xi}-x)(\mathrm{yi}-y) /(N-1) s_{x} s_{y}
$$

Where this test has significance, it suggests that two variables are related to one another, and the sign of that relation. It does not however imply causality.

\section{Factor analysis}

Factor analysis seeks out latent variables within a multivariate dataset: these are underlying factors that influence the distribution of the data, but are not themselves measured variables. It works by calculating the correlation matrix between the variables and its eigenvalues, looking to maximise the variance accounted for by each corresponding eigenvector. The process is initially carried out as a principal components analysis, but with a specific number of factors being extracted: it is common practice to quote eigenvalues $>1$, in accordance with Kaiser's criterion. The resulting component matrix is then rotated to ensure ease of interpretation. This study used a varimax orthogonal rotation, as it was considered unlikely that there would be correlation between factors. Stevens (1992) suggests that for a sample size of 150, a loading of more than about 0.4 is significant.

\section{Reliability analysis}

The reliability of the scales used in the questionnaire has been calculated using Cronbach's alpha:

$$
\alpha=N 2 \overline{\mathrm{Cov}} /\left(\Sigma s_{i}^{2}+\Sigma \mathrm{Cov}_{i}\right)
$$

This is a measure of the magnitude of the variance and covariance in the data, weighted according to the number of items and the average covariance. There is some debate over the acceptable threshold, with 0.7 taken by many authors. However, it should be noted that reverse-scaled items or items measuring slightly different variables will lower the value of the alpha since it assumes that the items are all measuring the same thing. Thus, it is realistic to expect that some sets of variables will give a lower alpha than 0.7. For some parts of this questionnaire, Cronbach's alpha was calculated using a normalised scale - the ratings given by the respondents were reversed in order to align the object of the scale as far as possible.

\section{References}

Aiuppa A, Bertagnini A, Métrich N, Moretti R, Di Muro A, Liuzzo M, Tamburello G (2010) A model of degassing for Stromboli volcano. Earth Planet Sci Lett 295(1-2):195-204

Aspinall WP (2006) Structured elicitation of expert judgement for probabilistic hazard and risk assessment in volcanic eruptions. In: Mader H, Coles S, Connor C, Connor L (eds) 
Statistics in volcanology, vol 1. Geological Society of London, Special Publications of IAVCEI, London, pp 15-30

Aspinall WP (2010) A route to more tractable expert advice. Nature 463:294-295

Aspinall WP, Woo G, Voight B, Baxter PJ (2003) Evidence-based volcanology: application to eruption crises. J Volcanol Geotherm Res 128:273-285

Bellucci F, Woo J, Kilburn C, Rolandi G (2005) Ground deformation at Campi Flegrei, Italy: Implications for hazard assessment. Geological Society, London, Special Publications 269: $141-157$.

Benoit JP, McNutt SR (1997) New constraints on source processes of volcanic tremor at Arenal Volcano, Costa Rica, using broadband seismic data. Geophys Res Lett 24(4):449-452

Bonafede M (1991) Hot fluid migration: an efficient source of ground deformationapplication to the 1982-1984 crisis at Phlegrean Fields, Italy. J Volcanol Geotherm Res 48:187-198

Brown MB (2009) Science in democracy: expertise, institutions and representation. MIT Press, Cambridge

Burton MR, Allard P, Mure F, Oppenheimer C (2003). FTIR remote sensing of fractional magma degassing at Mount Etna, Sicily. In: Oppenheimer C, Pyle DM, Barclay J, (eds.) Volcanic degassing. Special Publications. London, The Geological Society

Burton MR, Allard P, Mure F, La Spina A (2007) Magmatic gas composition reveals the source depth of slug-driven strombolian explosive activity. Science 317(5835):227

Burton MR, Caltabiano T, Mure F, Salerno GG, Randazzo D (2009) SO2 flux from Stromboli during the 2007 eruption: Results from the FLAME network and traverse measurements. J Volcanol Geotherm Res 182:214-220

Cashman KV, Taggart JE (1983) Petrologic monitoring of 1981 and 1982 eruptive products from Mount St. Helens. Science 221:1385-1387

Chester DK (2005) Theology and disaster studies: The need for dialogue. J Volcanol Geotherm Res 146(4):319-328

Chouet BA (1996) New methods and future trends in seismological volcano monitoring. In: Scarpa R, Tilling RI (eds) Monitoring and mitigation of volcano hazards. Springer, New York

Chouet BA et al (2003) Source mechanisms of explosions at Stromboli volcano, Italy, determined from moment-tensor inversions of very-long-period data. J Geophys Res 108(B1):2019

Collins HM (1985) Changing order: Replication and induction in scientific practice. Sage Publications, London 
Collins HM (2004) Interactional expertise as a third kind of knowledge. Phenomenol Cogn Sci 3:125-143

Collins HM, Evans R (2002) The third wave of science studies: studies of expertise and experience. Soc Stud Sci 32(2):235-296

Collins HM, Evans R (2007) Rethinking expertise. University of Chicago Press, Chicago

Corsaro RA, Miraglia L (2005) Dynamics of 2004-2005 Mt. Etna effusive eruption as inferred from petrologic monitoring. Geophys Res Lett 32:L13302.

doi:10.1029/2005GL022347

Cronin SJ, Gaylord DR, Charley D, Alloway BV, Wallez S, Esau JW (2004) Participatory methods of incorporating scientific with traditional knowledge for volcanic hazard management on Ambae Island, Vanuatu. Bull Volcanol 66(7):652-668

De Angelis S, Bass V, Hards V, Ryan G (2007) Seismic characterisation of pyroclastic flow activity at Soufriere Hills Volcano, Montserrat, 8 January 2007. Nat Hazards Earth Syst Sci 7(4):467-472

Donovan K (2009) Doing social volcanology: exploring volcanic culture in Indonesia. Area 42(1):117

Druitt TH, Kokelaar BP (eds) (2002) The eruption of the Soufriere Hills Volcano, Montserrat, from 1995 to 1999. London, Geological Society of London

Edmonds M, Pyle D, Oppenheimer C (2001) A model for degassing at the Soufrière Hills Volcano, Montserrat, West Indies, based on geochemical data. Earth Planet Sci Lett 186(2):159

Edmonds M, Herd RA, Galle B, Oppenheimer C (2003) Automated, high time-resolution measurements of SO2 flux at Soufriere Hills Volcano, Montserrat. Bull Volcanol 65(8):578586

Edmonds M, Aiuppa A, Humphreys M, Moretti R, Giudice G, Martin RS, Herd RA, Christopher T (2010) Excess volatiles supplied by mingling of mafic magma at an andesite arc volcano. Geochem Geophys Geosyst 11:Q04005. doi:10.1029/2009GC002781

Ewert JW, Newhall CG (2004) Status and challenges of volcano monitoring worldwide. In Proceedings of the 2nd International Conferenc-ze on Volcanic Ash and Aviation Safety, June 21-24, 2004, Alexandria, Virginia: Office of the Federal Coordinator for Meteorological Services and Supporting Research, session 2, p. 9-14

Ewert J, Guffanti M, Murray TL (2005) An assessment of volcanic threat and monitoring capabilities in the United States: NVEWS framework for a national volcano early warning system. USGS OPEN-FILE REPORT 2005-1164 
Fialko Y, Khazan Y, Simons M (2003) Deformation due to a pressurized horizontal circular crack in an elastic half-space, with applications to volcano geodesy. Geophys J Int 146(1):181-190

Field A (2000) Discovering statistics using SPSS. Sage, London

Fischer F (2010) Democracy and expertise: reorienting policy inquiry. Oxford University Press, Oxford

Foroozan R, Elsworth D, Voight B, Mattioli G (2010) Dual reservoir structure at Soufriere Hills Volcano inferred from continuous GPS observations and heterogeneous elastic modelling. Geophys Res Lett 37:L00E12

Galle B, Johansson M, Rivera C, Zhang Y, Kihlman M, Kern C, Lehmann T, Platt U, Arellano S, Hidalgo S (2010) Network for Observation of Volcanic and Atmospheric Change (NOVAC) - a global network for volcanic gas monitoring: network layout and instrument description. J Geophys Res 115:D05304. doi:10.1029/2009JD011823

Geertz C (1973) The interpretation of cultures. Basic Books, New York Gibbons M, Limoges C, Nowotny H, Schwartzman S, Scott P, Trow M (1994) The new production of knowledge: the dynamics of science and research in contemporary societies. Sage, London

Giddens A (2010) The politics of climate change. Polity Press, Cambridge

Hanks TC, Abrahamson NA, Boore DM, Coppersmith KJ, Knepprath NE (2009) Implementation of the SSHAC guidelines for level 3 and 4 PSHAs - experience gained from actual applications. USGS Open File Report 2009-1093

House of Commons Science and Technology Committee (2004) The use of science in UK International Development Policy. Thirteenth Report of Session 2003-2004. Volume II. House of Commons, London

Hulme M (2009) Why we disagree about climate change: understanding controversy, inaction and opportunity. Cambridge University Press, Cambridge

Hulme M, Mahony M (2010) Climate change: what do we know about the IPCC? Prog Phys Geogr 34(5):705-718

Jackson DB, Kauahikaua J, Zablocki CJ (1985) Resistivity monitoring of an active volcano using the controlled-source electromagnetic technique: Kilauea, Hawaii. J Geophys Res 90(B14):12,545-12,555. doi:10.1029/JB090iB14p12545

Jasanoff S (1990) The Fifth Branch: science advisors as policymakers. Harvard University Press, Cambridge

Jasanoff S (2003a) Breaking the waves in science studies: comment on H.M. Collins and Robert Evans, The Third Wave of Science Studies. Soc Stud Sci 33(3):389-400 
Jasanoff S (2004) The co-production of science and the social order. Routledge, Abingdon

Jasanoff S (2005) Designs on nature: science and democracy in Europe and the United States. Princeton University Press, Princeton

Jordan TH, Chen Y-T, Gasparini P, Madariaga R, Main I, Marzocchi W, Papadopoulos G, Sobolev G, Yamaoka K, Zschau J (2011) Operational earthquake forecasting: state of knowledge and guidelines for implementation. findings and recommendations of the International Commission on Earthquake Forecasting for Civil Protection, Rome, Italy: Dipartimento della Protezione Civile, Ann. Geophys 54(4):315-391

Jousset P, Mori H, Okada H (2003) Elastic models for the magma intrusion associated with the 2000 eruption of Usu Volcano, Hokkaido, Japan. J Volcanol Geotherm Res 125(1-2):81106

Kern C, Deutschmann T, Vogel L, Wöhrbach M, Wagner T, Platt U (2010) Radiative transfer corrections for accurate spectroscopic measurements of volcanic gas emissions. Bulletin of Volcanology 72(2):233-247

Kumagai H, Chouet BA (1999) The complex frequencies of long-period seismic events as probes of fluid composition beneath volcanoes. Geophys J Int 138:F7-F12. doi:10.1046/j.1365-246X.1999.00911.x

Lahr J, Chouet B, Stephens C, Power J, Page R (1994) Earthquake classification, location, and error analysis in a volcanic environment: implications for the magmatic system of the 1989-1990 eruptions at Redoubt Volcano, Alaska. J Volcanol Geotherm Res 62:137-151

Latour B (1987) Science in action: how to follow scientists and engineers through society. Harvard University Press, Cambridge

Lindsay J, Marzocchi W, Jolly G, Constantinescu R, Selva J, Sandri L (2010) Towards realtime eruption forecasting in the Auckland Volcanic Field: application of BET_EF during the New Zealand national disaster exercise 'Ruaumoko'. Bull Volcanol 72:185-204

Marzocchi W, Woo G (2007) Probabilistic eruption forecasting and the call for an evacuation. Geophys Res Lett 34:L22310

Marzocchi W, Woo G (2009) Principles of volcanic risk metrics: theory and the case study of Mount Vesuvius and Campi Flegrei, Italy. J Geophys Res. doi:10.1029/2008JB005908

Marzocchi W, Zechar JD (2011) Earthquake forecasting and earthquake prediction: different approaches for obtaining the best model. Seismol Res Lett 82(3):442-448

Marzocchi W, Sandri L, Gasparini P, Newhall C, Boschi E (2004) Quantifying probabilities of volcanic events: the example of volcanic hazard at Mount Vesuvius. J Geophys Res. doi:10.1029/2004JB003155

Marzocchi W, Sandri L, Selva J (2008) BET_EF: a probabilistic tool for long- and short-term eruption forecasting. Bull Volcanol 70(5):623-632 
McGonigle AJS, Oppenheimer C (2003) Optical sensing of volcanic gas and aerosol emissions. In: Oppenheimer C, Pyle DM, Barclay J (eds) Volcanic degassing. The Geological Society, London

McNutt SR (1996) Seismic monitoring and eruption forecasting of volcanoes: a review of the state-of-the-art and case histories. In: Scarpa R, Tilling R (eds) Monitoring and mitigation of volcano hazards. Springer, Berlin

Mogi K (1958) Relations between the eruptions of various volcanoes and the deformations of the ground surfaces around them. Bull Earthq Res Inst, Univ Tokyo 36:99-134

Morgan MG, Dowlatadasi H, Henrion M, Keith D, Lempert R, McBride S, Small M, Wilbanks T (2009) Best practice approaches for characterising, communicating and incorporating scientific uncertainty in decisionmaking. US Climate Change Science Program, Washington

Mori T, Burton MR (2006) The SO2 camera: a simple, fast and cheap method for groundbased imaging of SO2 in volcanic plumes. Geophys Res Lett 33:L24804.

doi:10.1029/2006GL027916

Neuberg JW, Baptie B, Luckett R, Stewart R (1998) Results from the broadband seismic network on Montserrat. Geophys Res Lett 25(19):3661-3664

Neuberg JW, Tuffen H, Collier L, Green D, Powell T, Dingwell D (2006) The trigger mechanism of low-frequency earthquakes on Montserrat. J Volcanol Geotherm Res 153(12):37-50

Newhall C, Hoblitt RP (2002) Constructing event trees for volcanic crises. Bull Volcanol $64: 3-20$

Newhall C, Punongbayan R (1996) The narrow margin of successful volcanic-risk mitigation. In: Scarpa R, Tilling RI (eds) Monitoring and mitigation of volcano hazards. Springer, New York, pp 807-832

Oppenheimer C, Edmonds M, Francis P, Burton M (2002) Variation in HCl/SO2 gas ratios observed by Fourier transform spectroscopy at Soufriere Hills Volcano, Montserrat. In: Druitt T, Kokelaar B (eds) The eruption of the Soufriere Hills Volcano, Montserrat, 1995-1999. Geological Society, London, Memoir 21

Oppenheimer C, Pyle DM, Barclay J (eds) (2003) Volcanic degassing. London, The Geological Society

Rayner S (2003) Democracy in the age of assessment: reflections on the roles of expertise and democracy in public-sector decision making. Sci Public Policy 30(3):163-170

Ripepe M, De Angelis S, Lacanna G, Voight B (2010) Observation of infrasonic and gravity waves at Soufriere Hills Volcano, Montserrat. Geophys Res Lett 37:L00E14 
Roman DC, Neuberg JW, Luckett RR (2006) Assessing the likelihood of volcanic eruption through analysis of volcano-tectonic earthquake fault-plane solutions. Earth Planet Sci Lett 248(1-2):244-252

Rowe CA, Aster RC, Kyle PR, Schlue JW, Dibble RR (1998) Broadband recording of Strombolian explosions and associated very-long-period seismic signals on Mount Erebus Volcano, Ross Island, Antarctica. Geophys. Res. Lett. 25(13):2297-2300

Rymer H (1994) Microgravity change as a precursor to volcanic activity. J Volcanol Geotherm Res 61(3-4):311

Salerno GG et al (2009a) Three-years of SO2 flux measurements of Mt. Etna using an automated UV scanner array: comparison with conventional traverses and uncertainties in flux retrieval. J Volcanol Geotherm Res 183(1-2):76-83

Salerno GG, Burton MR, Oppenheimer C, Caltabiano T, Tsanev V, Bruno N (2009b) Novel retrieval of volcanic SO2 abundance from ultraviolet spectra. J Volcanol Geotherm Res 181(1-2):141-153

Sandri L, Marzocchi W, Zaccarelli L (2004) A new perspective in identifying the precursory patterns of eruptions. Bull Volcanol 66(3):263-275

Shackley S, Wynne B (1995) Global climate change: the mutual construction of an emergent science-policy domain. Sci Public Policy 22(4):218-230

Shackley S, Wynne B (1996) Representing uncertainty in global climate change science and policy: boundary-ordering devices and authority. Sci Technol Hum Values 21(3):275-302

Sigmundsson F, Hreinsdóttir S, Hooper A, Árnadóttir T, Pedersen R, Roberts MJ, Óskarsson N, Auriac A, Decriem J, Einarsson P, Geirsson H, Hensch M, Ófeigsson BG, Sturkell E, Sveinbjörnsson H, Feigl KL (2010) Intrusion triggering of the 2010 Eyjafjallajökull explosive eruption. Nature 468:426-430

Somekh B, Lewin C (eds) (2005) Research methods in the social sciences. Sage, London Sparks RSJ (2003) Forecasting volcanic eruptions. Earth Planet Sci Lett 210:1-15

Sparks RSJ, Young SR (2002) The eruption of Soufriere Hills Volcano, Montserrat (19951999): overview of scientific results. Geol Soc Lond Mem 21(1):45-69

Spiegelhalter DJ, Riesch H (2011) Don't know, can't know: embracing deeper uncertainties when analysing risks. Philosophical Transactions of the Royal Society A: Mathematical, Physical and Engineering Sciences 369(1956):4730-4750. doi:10.1098/rsta.2011.0163

Stevens JP (1992) Applied multivariate statistics for the social sciences. Hillsdale, NJ: Erlbaum. 
Stirling A (2007) Risk, precaution and science: towards a more constructive policy debate. EMBO Rep 8(4):309-315

Stirling A (2008) Opening up and closing down. Sci Technol Hum Values 33(2):262-294

Tilling RI (2008) The critical role of volcano monitoring in risk reduction. Adv Geosci 14:311

Traweek S (1988) Beamtimes and lifetimes: the world of high-energy physicists. Harvard University Press, Harvard

Voight B, Hoblitt RP, Clarke AB, Lockhart AC, Miller AD, Lynch L, McMahon J (1998) Remarkable cyclic ground deformation monitored in real-time on Montserrat, and its use in eruption forecasting. Geophys Res Lett 25(18):3405-3408

Voight B, Sparks RSJ, Miller AD, Stewart RC, Hoblitt RP, Clarke AB, Ewart J, Aspinall WP, Baptie B, Calder ES, Cole PD, Druitt TH, Hartford CL, Herd RA, Jackson P, Lejeune AM, Lockhart AB, Loughlin SC, Luckett R, Lynch L, Norton GE, Robertson R, Watson IM, Watts R, Young SR (1999) Magma flow instability and cyclic activity at Soufriere Hills Volcano, Montserrat, British West Indies. Science 283:1138-1142

Voight B, Hidayat D, Sacks S, Linde A, Chardot L, Clarke A, Elsworth D, Foroozan R, Malin P, Mattioli G, McWhorter N, Shalev E, Sparks RSJ, Widiwijayanti C, Young SR (2010) Unique strainmeter observations of vulcanian explosions, Soufrière Hills Volcano, Montserrat, July 2003. Geophys Res Lett 37:L00E18

Wadge G, Mattioli G, Herd R (2006) Ground deformation at Soufriere Hills Volcano, Montserrat, during 1998-2000 measured by radar interferometry and GPS. J Volcanol Geotherm Res 152(1-2):157-173

Wadge G, Herd R, Ryan G, Calder ES, Komorowski JC (2010) Lava production at the Soufriere Hills Volcano, Montserrat, 1995-2009. Geophys Res Lett 37:L00E03

Watts RB, Herd RA, Sparks RSJ, Young SR (2002) Growth patterns and emplacement of the andesitic lava dome at Soufriere Hills Volcano, Montserrat. In: Druitt T, Kokelaar B (eds) The eruption of the Soufriere Hills Volcano, Montserrat, 1995-1999. Geological Society, London, Memoir 21

Wynne B (1992) Uncertainty and environmental learning: reconceiving science and policy in the preventive paradigm. Glob Environ Chang 2(2):111-127

Wynne B (2003) Seasick on the third wave? Subverting the hegemony of propositionalism. Soc Stud Sci 33(3):401-417

Wynne B, Felt U, Callon M, Gonçalves M, Jasanoff S, Jepsen M, Joly P-B, Konopasek Z, May S, Neubauer C, Rip A, Siune K, Stirling A, Tallacchini M (2007) Taking European knowledge society seriously. Expert Group on Science and Governance. European Commission D-G Research, Science Economy and Society Directorate, Brussels 
Young SR, Sparks R, Aspinall W, Lynch LL, Miller A, Robertson REA, Shepherd JB (1998) Overview of the eruption of Soufriere Hills Volcano, Montserrat, 18 July 1995 to December 1997. Geophys. Res. Lett. 25(18):3389-3392

Zlotnicki J, Le Mouël JL, Kanwar R, Yvetot P, Vargemezis G, Menny P, Fauquet F (2006) Ground-based electromagnetic studies combined with remote sensing based on DEMETER mission: a way to monitor active faults and volcanoes. Planet Space Sci 54:541-557 